\title{
BRIDGING GAPS THROUGH FEMINIST PEDAGOGY: TEACHING ABJECTION IN A POSTCOLONIAL LITERATURE COURSE
}

\section{Antonia Navarro-Tejero*}

\begin{abstract}
This paper engages with teaching gender, caste, and sexuality in the context of Spanish Higher Education. I will examine my experience of teaching Githa Hariharan's "The Remains of the Feast," Arundhati Roy's The God of Small Things and Shobha Dé's Strange Obsession to conclude by reflecting on the value of teaching these issues and texts from a feminist perspective.
\end{abstract}

Key words: feminist pedagogy, abjection, South Asian women writers

This paper focuses on how I teach abjection in Githa Hariharan's short story "The Remains of the Feast," Arundhati Roy's The God of Small Things and Shobha Dé's Strange Obsession. Since feminist pedagogy is concerned with notions of power and authority, a critique of the representation of racialized and queer characters in their entity as structurally disciplined subjects is located within feminism. bell hooks (2000) believed that the concept of 'otherness' can also be taken to the classroom, so it can be applied to a feminist pedagogy. Therefore, the underlying questions generated in our class discussions form two interrelated groups: What kind of source do I use to get my knowledge from? Does my conception of morality belong to a group? We base our analysis on Michel Foucault's (1978) theoretical framework, which explores the relations between power and knowledge, highlighting the idea that power is not exclusively exercised through repression, as it simultaneously operates through the approval/disapproval of specific actions.

The privileging of rationalism over emotions proposed by Freire (1968) has "set up as its opposite an irrational Other, which has been understood historically as the province of women and other exotic Others" (Ellsworth 1989: 94). According to Belenky, an alternative epistemological framework that acknowledges the inherent connection between power and knowledge needs to be offered (1986: 3). In our postcolonial literature course, it is important that the arrangements of gender, caste, and sexuality can be approached by tuning them to affects (noticing and observing), as this recognition can be integrated into the already

\footnotetext{
* Assist. Prof. PhD at University of Cordoba, Spain, e-mail: ff1natea@uco.es. The author wishes to acknowledge the funding provided by the Spanish Ministry of Economy and Competitiveness (Research Project "Bodies in Transit", ref. FFI2013-47789-C2-1-P).
} 
established research methodologies (traditionally relied on text analysis). Experienced feelings and the emotions derived from the literary texts are essential in our course before we process a response to the stimulus. According to James (1991), in order to assist students in separating feelings from facts and manage emotions, we could require them to keep a journal in which they explore reactions to and reflections on emotional content aroused by the course. Walker (1993), for example, states that she asks students to record their reactions to each class session in a journal where they describe incidents they have witnessed or about which they have learned, including discussions with family and friends, and their reactions, that are related to the course content.

The first novel that students read in the course is The God of Small Things. Emotions are shared during the first class discussion, which are usually related to suffering, pity, and sometimes hope. A common feeling among the students is that of self-condemnation for belonging to a "more civilized country" (which leads to relief) and a need to help (saving the protagonists). The distance between "them and us" is dramatically bigger at this stage. At the brainstorming session students are questioned if those emotions are genuine. The discussion is governed by concepts such as "paternalism" and "eurocentrism" (coined by Postcolonial Theory) and we look into the possibility of having reproduced paternalist feelings due to the Catholic morality and the Eurocentric lenses we all share as they are embedded in our society.

Then, students read Butler's chapter "Survivability, Vulnerability, Affect," to discuss her argument that affective responses are mediated (2009: 34). In order to dismantle this assumption, we make an introspection about the Spanish social system*. Students come up with the recent case of Catholic nuns of Indian origin who came to Spain fifteen years ago when they were minors and have been kept in a Mercedarias de Santiago convent in slave conditions under threats of deportation. Students also call attention to the several declarations that Catholic priests have recently made regarding their misogynist views on women. As a consequence, the distance between "them and us" is shortened.

We discuss around the question "Which groups are marginalized in your country? And how are they marginalized?" Students are ready to analyze the literary texts in solidarity, understanding their context and complexities, but being critical enough to find a common structure. They come to understand that ethnic differences are related to power systems just like gender differences are constructed by patriarchy. And we also learn that caste has a modern face, though we tend to deny its existence today. We go on reading Hariharan's short story to realize that high caste women are also oppressed as their bodies are

\footnotetext{
* Here we can also resort and discuss other social systems as there are many Erasmus+ students who attend the lectures.
} 
disciplined and regulated to support the system. Micro-violence and subtle abuse are difficult to perceive and to admit, as they are naturalized and interiorized. We discuss issues such as the glass-ceiling and the differences between "same opportunities," "effective equality," and "justice."

We then read the novel Strange Obsession to bring up the topic of "representation" and revolve around the question if all homosexual people are judged in the same way in our countries (Some of the questions posed are: Are all gays equal? Are high class gays in power positions accepted the same way as poor gays? Are lesbians stereotyped in your country as women with unhappy heterosexual past experiences?). We then read some excerpts from Foucault's History of Sexuality and Discipline and Punishment regarding the basis for medical treatment of homosexuality.

Since the representation of the lesbian body in Strange Obsession is related to the notion of nationhood, a few questions are proposed for discussion: Can dalits bring their food culture at a public place in India? What is Indian food culture at all; is beef included in it? Can Muslims bring their clothes culture at a public place in Spain? What is Spanish clothes culture; is the veil included in it? Are South Indians treated the same way as fair Indians? Does language matter? Are Andalusians treated the same way as any other Spanish citizen? Does language and accents matter? The hierarchies could be informal, but they condition the professional and personal relationships. How are gypsies described in the official Spanish language dictionary? Is intercaste marriage socially accepted in India? Is intermarriage desirable in Spanish society? These are chastening questions which may vary in each academic year depending on the students' nationalities and interests. Contexts are different, but both Indian and Spanish nation are defined as democracies, however they are not practicing real equality. In this way, we come to understand how caste works in patriarchal societies. Our interest relies not on learning how caste works in India, but on reflecting upon how unequal relations are products of global power structures that go beyond cultural or religious boundaries. We can only trespass borders when a mirror is given to the students in literature.

We try to be as much experiential as possible in the classroom, encouraging an active and feminist environment. This is why we find the integration of extracurricular activities into the students' lives especially useful. Students are offered a plethora of options and are encouraged to propose new entities where they can work as volunteers in exchange of an amount of credits. Keeping that in mind, we created back in 1996 the Permanent Seminar on India Studies, which has helped consolidate the teaching of South Asian literature and cultures at our University. It provides students with a personal contact with Indian artists, fiction writers, academicians, students, etc., thus helping them experience a sense of a real world different from their own. The caste system 
forms a structure difficult to understand for our students, as they expect me to define it in simple terms and offer a catalogue of possibilities. The idea that Hindu societies share an established moral code in contraposition to western lack of hierarchies, supports clear cut boundaries between "them" and "us."

We had the chance to invite the reputed scholar Susie Tharu to give a talk about dalit culture. This coincided with the release of her two volumes on New Dalit Writing from South India. On another occasion, we were offered a talk by a dalit young man from Anantapur, and in still another occasion Janet Chawla visited us to talk about dalit traditional midwives (dais).

We make use of the Flipped Classroom, as students read and/or watch the material online at their own pace, and we discuss their feelings and thoughts in seminar-style format inside the classroom, provoking the most interesting and engaging debates. Moreover, we leave fora of discussions open in the online platform (moodle) during the whole course, where they have open access to recorded lessons, videos, articles and other resources, and can communicate with each other without the restrictions of a timetable. In this way, we make sure that students of all abilities can follow the course. The learning process is thus, engaging, authentic, relevant, critical and reflective, where the expression of emotions is protected. A number of articles are uploaded in moodle so that students can read them at their convenience. In class, we identify a common framework of oppression, based on the concepts of pollution and taboo, which transcends boundaries.

Following are some notes about the three fictional texts that are part of the syllabus and deal with the topic of abjection.

In the three texts selected from the course syllabus, there is a protagonist who crosses prohibited borders and transforms her/himself into an abject body whose desires go beyond the thinkable, as Kristeva argued regarding abjection, "beyond the scope of the possible, the tolerable, the thinkable" (1982: 1). For Kristeva, the abject manifests in anything in fact that threatens rigid boundaries and evokes powerful fears of filth, pollution, contamination, and defilement. Regarding the concepts of pollution and contamination, Mary Douglass (1966: 140) in her Purity and Danger: An Analysis of the Concepts of Pollution and Taboo, points out that India's lower castes are kept in their place because of effective social sanctions, and the edifice of caste political and economic forces help to maintain the system all the way up. Physical crossing of the social barrier is treated as a dangerous pollution, with many consequences. The polluter becomes a doubly wicked object of reprobation, first because she crossed the line and second because she endangered others.

According to Kristeva's theory of abjection, the cadaver is the limit and the most sickening of wastes, a border that becomes an object as "I" is expelled (1982: 
3-4). As the abject threatens life, and must be radically excluded from the place of the living subject, the abject characters die in the three fictional texts. These characters are clear exponents of abjection, as they are considered perverse because according to Kristeva's definition of abject, they "neither give up nor assume a prohibition, a rule, or law; but turn them aside" (1982: 15). When we are propelled into the world of the abject, our imaginary borders disintegrate and the abject becomes a tangible threat because our identity system and conception of order has been disrupted. The abject is located in a liminal state that is on the margins of two positions. Kristeva keeps on arguing that the abject has only one quality of the object -that of being opposed to I. It lies outside, beyond the set, and does not seem to agree to the latter's rules of the fame. And yet, from its place of banishment, the abject does not cease challenging its master. What disturbs identity, system, order is the cause of abjection "the in-between, the ambiguous, the composite" (Kristeva 1982: 16).

In The God of Small Things, Ammu used to cross the river to meet her lover Velutha at the other side, away from the façade played in the Ayemenem house, crossing over what Kristeva calls "the dichotomous categories of Pure and Impure, Prohibition and Sin, Morality and Immorality" (Roy 1997: 16).

In "The Remains of the Feast," Rukmini, as a consequence of having been polluted by low caste people, becomes a polluting dying woman, as she dared to also cross over Kristeva's dichotomous categories. Finally, in Strange Obsession The lesbian abject in the novel is represented as mentally unstable and in need of treatment and psychological counselling that can medically 'cure' and 'correct' her behavior; Minx is labelled as a dangerous person, a maniac and a psychopath (Dé 1992: 163), someone who, following Kristeva's definition, "disturbs identity, system, order. What does not respect borders, positions, rules. The in-between, the ambiguous, the composite. The traitor, the liar, the criminal with a good conscience, the shameless rapist, the killer who claims he is a savior" (Dé 1992: 4). Same-sex desire is rendered as a western illness that taints the Indian culture.

To our understanding, we could make use of this theoretical methodology once we have reflected on it from the practice. The three texts have in common the rejection toward an interpretation of the difference as a natural phenomenon whose meanings are fixed and based on biological suppositions. The inequalities based on the difference are grafted in power relations which involve unequal access to material or symbolic resources which generate exclusion/inclusion and oppression/domination processes. As a consequence, the difference is not something which we have to 'tolerate,' because that would imply the existence of a majority dominant and leading group. As Simone de Beauvoir (1949) stated that one is not born, but rather becomes a woman, M. Jacqui Alexander and Chandra Talpade Mohanty declared (1997: 492) that one is not born as a woman 
of colour, but rather becomes one in the metropolis and then, she learns the hallmark of North American racism and its constructed racial barriers. The influential writer bell hooks (2000) said that any time that sexism is analysed, that there are new proposals to challenge patriarchy, and that new models of social interaction are created, we are developing feminist theory. According to the author, everything that we do in our lives is rooted in theory (see hooks 2000: 19). With these activities in class, we hope to achieve the perception of the difference not as a parallel category outside us, simplified in a description of what is not me, but as an identity constructed to establish barriers of belonging. In this way, by dismantling binomials, marginal positions disappear.

In short, this essay, written from a feminist perspective, has tried to advocate educational efforts representing solidarity in the social constructions of difference and to suggest pedagogical strategies to handle essentialism and the representation of the Other for the western paternalist conscience and to encourage students reflection upon their own societies regarding the oppressive systems of sexism, ethnocentrism and homophobia.

\section{References:}

Alexander, Mohanty 1997: Alexander M. J., C. T. Mohanty. Genealogies, Legacies, Movements. - In: Bhavnani K. (ed.). Feminism and 'Race'. Oxford, New York: Oxford University Press.

Belenkyet al. 1986: Belenky M. F., Clinchy B. M., Goldberger N. R., J. M. Tarule. Women's Ways of Knowing: The Development of Self, Voice, and Mind. New York: Basic.

Butler 2009: Butler J. Frames of War: When is Life Grievable? London: Verso.

Dé 1992: Dé S. Strange Obsession. New Delhi: Penguin.

de Beauvoir 1949: de Beauvoir S. El Segundo Sexo. Madrid: Cátedra.

Douglass 1966: Douglass M. Purity and Danger: An Analysis of the Concepts of Pollution and Taboo. London: Routledge.

Ellsworth 1989: Ellsworth E. Why Doesn't This Feel Empowering? Working Through the Repressive Myths of Critical Pedagogy. Harvard Educational Review 59 (3), 297-324.

Foucault 1978: Foucault M. The History of Sexuality Volume I: An Introduction, London: Penguin.

Freire 1968: Freire P. Pedagogy of the Oppressed. New York: Seabury Press.

Hariharan 1993: Hariharan G. The Art of Dying. New Delhi: Penguin.

hooks 2000: hooks b. Feminism is for Everybody: Passionate Politics. Cambridge, MA: South End Press.

James 1991: James J. Reflections on Teaching: Gender, Race, and Class. - Feminist Teacher 5(3): 9-15.

Kristeva 1982: Kristeva J. Powers of Horror: An Essay on Abjection. Trans. Leon S. Roudiez. New York: Columbia University Press.

Roy 1997: Roy A. The God of Small Things. New Dehli: IndiaInk. 
Tharu, Satyanarayana 2013: Tharu S., K. Satyanarayana. Steel Nibs are Sprouting: New Dalit Writing in South India Dossier 2: Kannada and Telugu. New Delhi: Penguin Books.

Tharu, Satyanarayana 2011: Tharu S., K. Satyanarayana. No Alphabet in Sight: New Dalit Writing in South India, Dossier 1: Tamil and Malayalam. New Delhi: Penguin Books.

Walker 1993: Walker A. J. Teaching about Race, Gender, and Class Diversity in United States Families. - Family Relations, Vol. 42 (3), 342-350. 